\title{
Tinjauan Filosofis Hubungan antara Pendidikan, Moral dan Agama
}

\author{
Sudarto Murtaufiq \\ Program Studi Pendidikan Agama Islam Universitas Islam Lamongan \\ E-mail: murtaufiq@unisla.ac.id \\ Victor Imaduddin Ahmad \\ Program Studi Pendidikan Agama Islam Universitas Islam Lamongan \\ E-mail: victorimaduddin109@gmail.com
}

\begin{abstract}
This article aims at discussing the relationship between morality and religion, and what the contribution of these two fields to education. They are are important instruments to be included in the curriculum. Moral education and religious education are specific forms of education, which are needed to realize a complete education. It does not mean that they will become the overall goal of education. Moral education teaches students the knowledge of what to do regarding behavior that affects their well-being or happiness and that of others, including an understanding of the reasons behind such moral behavior.
\end{abstract}

Keywords: Education, morality, religion

\section{Pendahuluan}

Secara umum dikatakan bahwa ada hubungan yang erat antara pendidikan dan moral atau antara pendidikan dan agama. Muncul pandangan bahwa pendidikan harus berkaitan dengan kehidupan moral peserta karena ajaran moral dan agama sangat penting dalam dunia pendidikan. ${ }^{1}$ Pendidikan akan berjalan efektif jika melibatkan ajaran-ajaran agama. Dengan demikian, pandangan perlunya membentuk teori tentang pendidikan, yaitu, teori bahwa pendidikan harus melibatkan konten agama dan moral adalah suatu keniscayaan. Teori itu juga mengatur semua lembaga pendidikan agar memperhatikan penempaan moral dan kepercayaan agama terhadap peserta didik. Para filsuf pendidikan dapat menunjukkan bahwa teori semacam itu mungkin bertumpu pada, penggunaan istilah 'pendidikan', itu sendiri yang secara implisit melekat di dalamnya unsur moral dan agama. ${ }^{2}$

\section{Moral dan Pendidikan}

Moral, atau moralitas, berkaitan dengan perilaku manusia yang dinilai dari sudut pandang normatif. Moral sangat berkepentingan dengan apa yang harus dilakukan, berbeda dari apa yang sebenarnya dilakukan. ${ }^{3}$ Kita dapat membedakan moral dari pertimbangan kehati-hatian, yaitu tentang apa yang seharusnya dilakukan terutama untuk kepentingan orang yang melakukan tindakan (moral) tersebut. Dalam hal ini, kebijaksanaan menekankan

\footnotetext{
${ }^{1}$ Mary Shanahan (ed), Does Religious Education Matter? (London: Routledge, 2016)

${ }^{2}$ Jacob Aikara, Education: Sociological Perspective (New Delhi: Rawat Publications, 2004), 81.

${ }^{3}$ George D. Pozgar, Legal and Ethical Issues for Health Professionals (Burlington: Jones\&Bartlett Learning, 2019), 5
} 
pentingnya melaksanakan tugas-tugas utama. Moralitas adalah tentang tindakan-tindakan yang mempengaruhi kepentingan dan kesejahteraan orang lain, serta diri kita sendiri.

Tentang seluruh bidang studi moral, kita dapat membuat poin berkaitan dengan pendidikan itu sendiri, yaitu anggapan bahwa moral berkaitan dengan hierarki dari serangkain aktivitas manusia. Pada level tertentu, ada praktik moral, seperti berkata jujur, menepati janji, dermawan dan lain-lain. Namun yang perlu dicermati di sini adalah adanya teori moral, yang mencoba memberikan penjelasan umum tentang, atau pembenaran, dan kesimpulan mengenai apa yang seharusnya dilakukan. Teori moral seperti utilitarianisme, intuisionisme, dan emotivisme termasuk dalam level ini. Bahkan, pada level yang lebih tinggi masih muncul analisis konsep dan telaahan teori-teori moral yang merupakan bagian dari filsafat moral. Filsuf moral sangat menaruh perhatian pada penggunaan bahasa moral yang sebenarnya, dengan konsep-konsep seperti 'baik' dan 'benar' atau 'tugas' dan 'kewajiban', serta dengan validitas dan penerimaan teori yang ditawarkan untuk membenarkan keputusan dan pertimbangan moral. Bahwa sangat mungkin ada hubungan atau "perjumpaan" antara temuantemuan yang dikemukakan oleh para ahli teori moral, filsuf moral dan filsuf pendidikan, terlebih jika pendidikan dianggap sebagai usaha yang didominasi oleh pertimbangan 'moral'. ${ }^{4}$

Tetapi hubungan yang tepat antara moral dan pendidikan dan sejauh mana keduannya terkait tidak mudah untuk dibangun secara konseptual idealistik. Sebenarnya, ada beberapa alasan mengapa studi pendidikan di masa lalu agak terlalu 'bermoral', dan bahwa beberapa ahli teori pendidikan dan filsuf pendidikan telah dituntun jauh lebih melangkah ke dalam labirin yang rumit tentang teori moral. Ini bukan untuk menyangkal bahwa filsuf moral memiliki pandangan dan gagasan-gagasan penting untuk dihadirkan kepada pendidik dan filsuf pendidikan. Namun yang perlu juga mendapat perhatian di sini bahwa filsafat moral adalah samudera luas dan membuka segala kemungkinan makna, sehingga filsuf pendidikan harus berhati-hati agar tidak tersesat di dalamnya.

Karena itu, jika moral memiliki unsur yang penting dalam pendidikan, kita mungkin bertanya: apa hubungan keduanya? Pertanyaan ini membutuhkan penyelidikan filosofis. Apakah hubungan itu diperlukan, karena moral sangat penting untuk pendidikan? Atau apakah hubungannya semata-mata karena saling tergantung satu sama lain, mengingat pendidikan dapat dan harus memasukkan beberapa konten moral?

Pandangan bahwa moral dan pendidikan harus dihubungkan muncul sebagian dari keyakinan bahwa pendidikan adalah inisiasi peserta didik ke dalam bidang pengetahuan dan pemahaman yang sangat bernilai. ${ }^{5}$ Pendidikan adalah persoalan normatif. Hal ini berimplikasi dan lebih sering dinyatakan daripada diperdebatkan adalah bahwa nilai atau kepatutan adalah kualitas moral, sehingga ketika seseorang mengajar matematika, sains atau sejarah misalnya, ia sejatinya sedang melayani tujuan moral. Versi kuat dari pandangan ini adalah bahwa nilai sebenarnya berasal dari konten moral dari disiplin-disiplin ilmu tersebut. Bahwa yang penting di dalamnya adalah kepedulian terhadap kebenaran, ketertiban, kedisiplinan, dan lain-lain yang dikategorikan sebagai unsur moralitas. Jika demikian, maka seluruh pendidikan akan menghadirkan aspek moralitas. Berbicara tentang pendidikan diluar pertimbangan moralitas akan menjadi kontradiksi dalam kandungan makna istilah pendidikan itu sendiri. Kita

\footnotetext{
${ }^{4}$ Lihat Saeeda Shah, Education, Leadership and Islam: Theories, Discource and Practices from Islamic Perspective (London and New York: Routledge, 2016), 45

${ }^{5}$ Norman J. Bull, Moral Education (New York: Rotledge, 2010), 96
} 
mungkin setuju bahwa untuk menjadi terdidik, apa yang diajarkan haruslah sesuatu yang bernilai, sesuatu yang layak dipelajari. Tetapi hal ini tidak berarti bahwa subyek atau mata pelajaran itu sendiri harus bernilai dalam arti moral positif per se.

Banyak dari disiplin akademis tradisional pada kenyataannya netral secara moral. Nilai disiplin akademis itu berkaitan dengan kegunaan atau kemanfaatan bagi peserta didik, atau sebagai pertimbangan penting dari aspek non-moral. Perhatian pada kebenaran, dalam arti akurasi, ketepatan, dan kesesuaian terhadap bukti (evidence) tidak terkait dengan nilainilai moral. Mereka memiliki lebih banyak kesamaan dengan penghargaan akan estetika. Poin ini dapat diperdebatkan dengan alasan bahwa sebenarnya ada 'etika kepercayaan', suatu nilai moral dalam mendapatkan kebenaran. Relevansi nyata dari 'moralitas yang sepadan' dengan moralitas di sini adalah bahwa tidak ada mata pelajaran yang akan dianggap bernilai dalam pengertian pendidikan jika itu tidak menyangkut dimensi moral; tetapi mata pelajaran mungkin layak dipelajari meskipun tidak memiliki dimensi 'moral'. Dengan demikian, mata pelajaran harus melewati lorong 'tes negatif' sehubungan dengan moralitas, bukan sebaliknya.

Pendekatan lain untuk menyatakan moralitas adalah bagian penting dari pendidikan adalah bahwa ada sejumlah 'bentuk' pengetahuan dan pemahaman yang berbeda yang telah dikembangkan oleh manusia. ${ }^{6}$ Berbagai cara melihat dunia, yang semuanya penting bagi pemahaman (understanding) terhadap kondisi manusia secara memadai atau rasional sudah tidak lagi terelakkan. Matematika adalah salah satunya, belum lagi sains, estetika dan lainlain. Inisiasi ke dalam bentuk pengalaman yang berbeda ini diperlukan untuk dijadikan pertimbangan yang rasional. Dikatakan bahwa moral, seperti agama, adalah salah satu cara memahami situasi manusia, dan bahwa tanpa masuk ke dalam bidang-bidang khusus ini, manusia tidak memiliki dasar rasionalitas untuk bidang khusus ini. Jika demikian, maka pendidikan, yang merupakan sarana untuk menginisiasi kaum muda ke dalam berbagai bentuk pengetahuan ini, harus melibatkan inisiasi ke dalam aspek moral. Sebab kecuali jika itu dilakukan, peserta didik tidak dilengkapi dengan baik untuk bertindak sebagai makhluk rasional di bidang yang penting tersebut.

Argumen serupa dapat digunakan untuk membenarkan dimasukkannya masingmasing dan setiap bentuk yang berbeda; bahwa jika salah satu dari keduanya gagal, peserta didik tidak akan dipandang 'berpendidikan'. Pada titik ini bisa dikatakan bahwa argumen tersebut tergantung pada makna penetapan atau definisi yang diberikan untuk istilah 'pendidikan'. Jika 'pendidikan' dipahami sebagai inisiasi ke dalam sejumlah bentuk pengetahuan yang berbeda namun penting, dan moral diterima sebagai salah satu bentuk esensial itu, maka perlu bahwa pengajaran moral harus menjadi bagian dari pendidikan, dan pendidikan harus menjadi perhatian 'moral'. Namun, ini hanyalah masalah ketentuan. Kita selalu dapat menyangkal bahwa seseorang yang belum menjalani beberapa pengajaran moral 'berpendidikan baik', karena dengan ketentuan tersebut, 'berpendidikan baik' berarti pengajaran tersebut harus melibatkan pelatihan moral.

Tetapi untuk berbicara tentang 'pendidikan yang benar' adalah mengambil posisi yang tidak sepenuhnya sesuai dengan penggunaan populer. Tampaknya tidak masuk akal atau bertentangan jika dikatakan seseorang berpendidikan baik tetapi sama sekali tidak memiliki pemahaman moral. Kita mungkin harus mengatakan tentang orang seperti itu bahwa dia

\footnotetext{
${ }^{6}$ Cornelius J. Troost, Radical School Reform; Critique and Alternatives (Boston: Little, Brown, 1973), 110
} 
berpendidikan tetapi bahwa ada bidang-bidang pemahaman di mana dia kurang memahami aspek moral. Kita harus mengatakan sesuatu yang sama tentang seseorang yang, meskipun berpendidikan lain, tidak tahu apa-apa tentang sains, atau seni, atau kedokteran, atau hukum. Pendidikan bukan masalah semua atau tidak sama sekali dan tidak menahan istilah 'berpendidikan' dari mereka yang tidak mendapat informasi dalam satu atau dua bidang, betapapun pentingnya bidang-bidang ini.

Dengan demikian mungkin akan lebih benar untuk mengatakan bahwa pengajaran moral adalah bagian yang diinginkan dari pendidikan umum. Cara lain untuk mengatakan ini adalah dengan menganggap bahwa pendidikan moral bukanlah bagian penting dari pendidikan dalam arti bahwa setiap guru adalah atau harus menjadi guru moral. Ketika seorang guru mengajar matematika atau sejarah atau sains dia tidak, atau setidaknya dia tidak perlu, terlibat dalam pengajaran moral. ${ }^{7}$ Subjek-subjek ini, meskipun memiliki nilai, tidak 'dimuat secara moral'. Mereka netral dalam hal moral. Pendidikan moral adalah jenis pendidikan yang berbeda, seperti pendidikan matematika. Pendidikan moral dengan demikian merupakan bagian dari usaha pendidikan, dan perlu dalam arti praktis bahwa tanpanya pendidikan tidak lengkap. Tetapi itu tidak perlu dilibatkan dalam pendidikan talkala apa yang diajarkan harus layak dipelajari harus terlibat di dalamnya. Dengan kata lain, konten 'moral' bukan bagian dari definisi istilah 'pendidikan'. ${ }^{8}$ Untuk membuatnya demikian berarti membatasi istilah dengan cara yang tidak sesuai dengan pemahaman kita yang biasa tentangnya. Guru, tentu saja, dalam perannya sebagai pendidik terikat untuk mempraktikkan moralitas dalam pengajarannya. Dia terikat untuk menggunakan prosedur yang dapat diterima secara moral dan untuk menunjukkan rasa hormat kepada murid-muridnya sebagai pribadi. Tetapi mengajar yang dibenarkan secara moral tidak sama dengan pelibatan diri dalam pendidikan moral.

\section{Pendidikan Moral}

Mengingat bahwa moralitas adalah bagian yang penting meskipun tidak secara logis diperlukan dalam pendidikan umum, pertanyaan yang sekarang harus dijawab adalah: apa yang harus disertakan dalam pendidikan moral? Pendidikan moral berkaitan dengan upaya mempengaruhi perilaku dan ini mengandaikan sejumlah pengetahuan yang harus diperoleh oleh peserta didik. Mereka tidak dilahirkan secara moral, sehingga bagian yang tak terpisahkan dari usaha ini adalah memberikan bekal dengan perangkat konseptual tertentu. Jelas bahwa seorang anak tidak akan dapat memilih untuk melakukan hal yang benar kecuali dia tahu apa itu benar. Dia tidak akan dapat menemukan pengertian tentang ajaran pentingnya menepati janji jika dia tidak tahu apa itu janji.

Dengan demikian, tidak ada gunanya memberitahu seorang anak bahwa dia tidak boleh mencuri jika dia tidak tahu arti 'mencuri', dan sebagainya. Dalam konteks ini, pengetahuan moral merupakan bagian yang sangat penting dari pendidikan moral. Penguasaan pengetahuan ini akan melibatkan pemahaman tentang konsep-konsep moral seperti 'benar', 'salah', 'tugas' dan 'kewajiban' selain juga pemahaman tentang aturan seperti 'Seseorang harus mengatakan yang sebenarnya, menepati janji, berbuat baik kepada orang lain, dan lain sebagainya. Bagaimana seorang anak diberi pengetahuan dan pemahaman

\footnotetext{
${ }^{7}$ Terence W. Moore, Philosophy of Education, (London: Routledge, 2010), 44

${ }^{8}$ Ibid.
} 
semacam ini adalah masalah pedagogi moral. Dua tugas utama, yaitu pertama, anak harus diinisiasi ke dalam bahasa 'moral'; dia harus diajari bagaimana memahami konsep dan harus belajar aturan. Kedua, dia harus didorong untuk bertindak sesuai dengan aturan. Ia harus didorong untuk berbicara kebenaran, menepati janji-janjinya, dan memperhatikan kepentingan orang lain. Aspek terakhir dari tugas ini adalah pelatihan moral, yaitu dengan menjadikan anak-anak bertindak dengan cara yang dapat diterima secara moral, sesuai dengan "bahasa" moral masyarakatnya. Ini adalah bentuk dasar moralitas: bertindak sesuai dengan ekspektasi sosial.

Tugas guru dalam pelatihan moral telah difasilitasi selama dua puluh atau tiga puluh terakhir melalui studi-studi terperinci, yang dilakukan oleh psikolog anak dan lainnya, mengenai cara di mana kesadaran moral anak bisa berkembang. Studi-studi ini, yang Piaget dan Kohlberg adalah contoh penting, tidak termasuk dalam bidang filsafat moral atau filsafat pendidikan, tetapi mereka masuk ke dalam teori pendidikan dengan memberikan informasi tentang cara di mana anak-anak berkembang dan memungkinkan guru terlibat dalam pelatihan moral lebih efektif dari pada yang mungkin bisa dilakukan. Kesimpulan umum berbeda antara satu teori dengan teori yang lain, tetapi teori-teori itu menganggap bahwa, seperti halnya dengan kehidupan intelektual anak, kesadaran moral seseorang akan berkembang secara bertahap. Ada tahap awal non-moralitas, di mana anak tidak benar-benar menyadari aturan atau kewajiban. Kemudian muncul tahap di mana aturan diakui dan umumnya dipatuhi, tetapi dianggap sebagai arbitrer dan dipaksakan dari luar, sementara kepatuhan diberikan hanya sebagai masalah kehati-hatian.

Tahap selanjutnya adalah ketika aturan diterima sebagai sesuatu yang tetap dan tidak dapat diubah karena bertolak persetujuan atau otoritas kelompok. Kemudian, anak sampai pada pemahaman tentang pentingnya aturan, sebagai batasan yang memungkinkan berlangsungnya kehidupan sosial, dan pada akhirnya mampu 'menginternalisasi' dan mengadopsi aturan-aturan tersebut untuk diri mereka sendiri. Kemajuan ini, dari posisi nonmoral ke posisi pengakuan dan penghargaan, dari heteronomi ke otonomi moral, dipandang sebagai urutan yang tidak masuk akal secara logis. Bagi Piaget, hal itu tergantung pada tingkat kematangan; sementara bagi Kohlberg itu adalah konsekuensi dari interaksi anak dengan kekuatan dan institusi sosial. ${ }^{9}$ Implikasi pedagogis adalah walaupun sedikit yang dapat dilakukan di sekolah tentang tahap perkembangan aktual, karena ini adalah masalah kematangan atau interaksi sosial, apa yang bisa dilakukan adalah memberikan pengajaran moral yang sesuai dengan tahap perkembangan yang telah dicapai anak pada waktu tertentu. Pelatihan moral dengan demikian sejajar dengan pelatihan intelektual. Ada poin-poin 'kesiapan' dalam kehidupan moral seseorang sebagaimana ada dalam kehidupan intelektualnya. Dengan demikian, pendidik moral harus menyadari aspek moral dan intelektual peserta didiknya dan mengatur pengajarannya sesuai dengan aspek-aspek tersebut.

Sejauh ini kita telah berurusan dengan satu aspek pengajaran moral, yaitu pelatihan moral, yang sangat berkepentingan dengan bagaimana anak menjaga aturan masyarakatnya. Masalah pokoknya adalah lebih dari sekadar dilatih secara moral, tetapi juga dididik secara moral. Hal ini berarti ada upaya sadar untuk membawanya ke posisi otonomi moral, di mana aturan itu adalah aturannya, aturan yang dipegangnya karena dia mengenalinya sebagai aturan

\footnotetext{
${ }^{9}$ Ibid., 45.
} 
yang harus dia sikapi dari pertimbangan kehati-hatian, pujian atau kesalahan. Ini berarti perlu dihadirkan argument atau alasan pentingnya aturan aturan, berikut mengapa aturan itu diberlakukan. Orang yang berpendidikan moral adalah orang yang tidak hanya tahu apa yang harus ia lakukan, tetapi juga tahu alasan mengapa ia harus melakukannya. Menghadirkan alasan ini sama sekali bukan perkara sederhana, dan di sinilah pendidik moral dapat melakukan penyelidikan lebih mendalam ke jantung filsafat moral. Filsuf moral tidak berkaitan dengan hanya menawarkan nasihat-nasehat moral, atau dengan membuat teori-teori moral, tetapi dengan klarifikasi konsep-konsep yang digunakan dalam wacana moral dan dengan penelitian cermat terhadap argumen yang digunakan dalam teori-teori moral. Apa yang dapat dia lakukan dengan membantu pendidik moral adalah dalam rangka menetapkan skema di mana pemikiran tentang moral dapat diberikan. Ini paling baik dilakukan dengan menetapkan struktur argumen moral. Argumen moral adalah sejenis silogisme secara terbalik, argumen dari kasus tertentu ke prinsip praktis umum. Anggaplah, misalnya, seorang guru membuat penilaian moral, bahwa tindakan tertentu salah, bahwa seorang anak telah berbohong dan seharusnya tidak melakukannya. Seandainya sekarang pelakunya bertanya: mengapa berbohong tidak dibenarkan? Guru harus memberikan alasan-alasan penilaiannya. Guru pun bisa menjawabnya karena adanya aturan moral yang harus dijalankan bahwa tidak ada yang boleh berbohong. Dalam banyak kasus, tidak diragukan lagi, seruan terhadap suatu aturan ini sudah cukup untuk memuaskan si penanya. Namun, seandainya anak itu mempertanyakan aturan: mengapa kita memiliki aturan seperti itu? Aturannya sekarang perlu dibenarkan. Ini akan melibatkan seruan kepada aturan tingkat tinggi, prinsip moral. Ini mungkin, misalnya: setiap orang harus berperilaku untuk menjaga perasaan, kepercayaan dan keamanan secara umum, dan berbohong mengancam perasaan saling percaya antarsesama. Sekali lagi, alasan ini mungkin cukup. Namun, jika si penanya menantang prinsip itu, alasan lebih lanjut harus diberikan, kali ini masih ada seruan terhadap prinsip yang lebih mendasar. Ini mungkin, misalnya: setiap orang harus berperilaku untuk menjaga perasaan, kepercayaan dan keamanan secara umum, dan berbohong mengancam perasaan saling percaya ini. Sekali lagi, alasan ini mungkin cukup. Namun, jika si penanya menantang prinsip itu, alasan lebih lanjut harus diberikan, kali ini masih ada seruan terhadap prinsip yang lebih mendasar. Ini mungkin: setiap orang harus bertindak untuk memberikan kesejahteraan dan pelayanan kepada manusia sebanyak mungkin.

Tentu saja, cara menjelaskan hal ini kepada seorang anak akan tergantung pada usia dan pemahamannya, tetapi bentuk argumen ini mendasari semua pendidikan moral, yang berbeda dari pelatihan moral. Apa yang telah dicontohkan di sini adalah pemberian alasan pada berbagai tingkat umum, dan pembenaran putusan semula telah dilakukan hingga ke titik di mana tidak ada alasan lebih lanjut yang dapat diberikan. Tidak ada alasan moral lebih lanjut yang dapat dikemukakan untuk mendukung prinsip moral yang mendasar. Tidak disarankan di sini bahwa prinsip dasar yang digunakan dalam contoh di atas adalah satusatunya yang dapat digunakan. Ini adalah prinsip yang menopang teori moral yang dikenal sebagai Utilitarianisme, yang menjadikan dasar pemikiran moral sejauh mana tindakan mendukung ke arah kebahagiaan atau kesejahteraan manusia. ${ }^{10}$ Ada prinsip dasar lain yang mungkin juga digunakan yang berasal dari teori-teori moral yang lain. Poin pentingnya

\footnotetext{
${ }^{10}$ Ray Billington, Living Philosophy: An Introduction to Moral Thought (London and Nw York: Routledge, 2003), 119
} 
adalah, bagaimanapun, pemikiran pada akhirnya melibatkan beberapa prinsip yang menjadi dasar dari seluruh argumen. Pendidikan moral, pada akhirnya, mengharuskan peserta didik menerima aturan dan prinsip sekaligus menjalankan aturan dan prinsip tersebut.

Kita harus waspada terhadap kemungkinan kesalahpahaman di sini. Pelatihan moral harus dibedakan dari pendidikan moral karena yang pertama membuat peserta didik melakukan apa yang harus dia lakukan sementara yang kedua melibatkan pemberian alasan yang memadai sebagai tugas moral dan membuat peserta didik menerima alasan-alasan yang diajukan. Tidak disarankan bahwa pelatihan moral harus didahulukan dan kemudian, pendidikan moral dimulai. Kedua proses harus berjalan bersama. Adalah penting bahwa anakanak harus dilatih secara moral, bahwa mereka harus melakukan hal yang benar karena kebiasaan. Ini membutuhkan aturan dan praktik, di mana orang tua dan guru memberlakukan standar perilaku tertentu pada anak-anak. Anak-anak harus belajar apa yang harus dilakukan, dan harus melakukannya, meski terkadang dengan berbagai macam tekanan. Tetapi pada saat yang bersamaan, mereka dapat diberikan penjelasan, sesuai dengan kemampuan mereka untuk menghargainya sesuai tahap perkembangan moral yang telah mereka capai. Seiring dengan bertambahnya usia anak dan menjadi lebih sadar akan masalah-masalah manusia dan sosial, pelbagai argumen dan alasan dapat diberikan dalam istilah yang lebih dewasa dan bisa diterima.

Apa yang penting untuk dikemukakan di sini adalah untuk dididik secara moral murid harus, pertama, memperoleh pengetahuan moral, pengetahuan tentang apa yang harus dia lakukan dan apa yang tidak boleh dilakukan. Kedua, ia harus memperoleh pengetahuan tentang jenis pembenaran. Dia harus tahu mengapa dia harus berperilaku dalam beberapa hal dan tidak dalam hal lain; ia harus memiliki alasan yang dibenarkan. Ketiga, ia harus bertindak secara moral karena keyakinan bahwa itu benar. Dia harus bertindak atas nama motif-motif moral. Untuk memenuhi semua persyaratan ini, seseorang harus matang secara moral.

\section{Pendidikan dan Pengajaran Moral}

Meskipun moralitas melibatkan pengetahuan dan praktik, namun itu tidak harus dijadikan salah satu mata pelajaran yang tersusun atau menempatkannya dalam kurikulum sekolah. Dalam hal ini, moralitas bukan bagian penting dari pendidikan dalam arti harus terlibat dalam semua mata pelajaran lain, tetapi bahwa itu, lebih tepatnya, semacam pendidikan khusus, yang juga bagi bidang-bidang umum lainnya, seperti matematika, sejarah atau sains. Pandangan seperti itu meberikan ruang bagi 'moralitas' sebagai disiplin yang terpisah. $^{11}$ Masalahnya adalah apakah pandangan ini akan bertentangan dengan praktik pendidikan kontemporer di mana, 'pendidikan moral', cenderung terkait dengan mata pelajaran lain. Bahkan beberapa di antaranya menjadi instrumen yang efektif dalam pengembangan, terutama pendidikan agama. Karena hubungan yang erat antara agama dan moral, pendidikan moral mungkin lebih mudah masukkan dalam pelajaran atau studi agama, sastra atau sejarah daripada, katakanlah, mata pelajaran geografi atau matematika. Memang, beberapa mata pelajaran yang mungkin berurusan dengan masalah moral menimbulkan beberapa kemungkinan kesulitan. Dapat dikatakan bahwa bukan urusan pengajaran sejarah atau pengajaran sastra yang menjadi pertimbangan moral. Namun, menjadi tugas peserta

\footnotetext{
${ }^{11}$ Lihat Paul Bloomfield, Morality and Self-Interest (Oxford: Oxford University Press, 2008), 95
} 
didik untuk memahami apa yang terjadi dalam sejarah, terutama mempelajari adanya unsur saling mempengaruhi sebab dan akibat historis. Dalam hal ini, peserta didik tidak belajar bagaimana cara bermoral tentang suatu hal atau mengambil pelajaran moral dari sejarah. Demikian juga, guru berkepentingan untuk memastikan peserta didiknya mendapatkan pemahaman sejarah, bukan menggunakan sejarah sebagai barometer untuk bermoral. Hal yang sama dapat dikatakan tentang studi sastra. Tokoh-tokoh seperti Aesop, La Fontaine dan Jane Austen semuanya adalah moralis, dan jika ingin mengajarkan pelajaran moral harus memberikan banyak contoh untuk dipelajari. Tetapi jika Aesop, La Fontaine, Shakespeare, Milton dan Jane Austen dipelajari sebagai tokoh-tokoh sastra, maka moralitas yang terkandung dalam tulisan atau karya mereka harus menjadi subjek pengetahuan dan pemahaman, sebagai bagian dari materi pelajaran, bukan sebagai bahan untuk pertimbangan moral. Hal ini tentu menjadi titik perdebatan yang membuka ruang diskusi yang menarik bagi semua pihak yang berkepentingan. Mungkin saja ada kaitan antara sejarah dan moralitas atau antara sastra dan moralitas, tetapi akan keliru jika menjadikan mata pelajaran sejarah dan sastra sebagai mata pelajaran 'moral'. ${ }^{12}$

Jika moralitas diajarkan sebagai bentuk pengetahuan yang berbeda, maka ia harus diajarkan dengan menggunakan "bahan-bahan" sejarah dan sastra yang sesuai; tetapi tidak tersusun dalam kurikulum untuk mata pelajaran sejarah atau sastra. Jika ada sesuatu yang diperselisihkan, maka pendidikan moral di sekolah paling baik dilakukan secara informal, dengan mengambil peluang dan kesempatan untuk penanaman kebenaran moral. Anak-anak harus mendapatkan aturan dan prinsip dan akhirnya menjadi sadar akan alasan pentingnya pendidikan moral dalam kehidupan mereka. Anak-anak dapat dibuat lebih peka terhadap kebutuhan dan perasaan orang lain dengan berbagai cara dalam kehidupan sehari-hari di kelas; bagaimana harus berinteraksi dengan hewan peliharaan, atau dengan anak-anak lain, dengan anak-anak berkebutuhan khusus atau kurang beruntung. Anak-anak juga diajarkan bagaimana berinteraksi dengan mereka yang lebih tua, atau membantu orang lain di luar sekolah, orang tua atau orang sakit misalnya. Guru biasanya memiliki banyak peluang yang bisa dimanfaatkan melalui diskusi kelas tentang masalah-masalah seperti perusakan lingkungan, perilaku seksual, kejahatan, tindakan rasis dan sejenisnya untuk memungkinkannya membuat keputusan-keputusan moral dan menghubungkannya dengan prinsip-prinsip moral. Mungkin dengan cara inilah pendekatan terhadap otonomi moral oleh anak bisa berjalan efektif.

\section{Agama dan pendidikan}

Sangat tepat untuk memasukkan bagian singkat tentang agama dan pendidikan di sini karena agama dan moral secara tradisional punya kaitan yang sangat erat. ${ }^{13}$ Hubungan antara keduanya terbuka untuk beragam argumen, tetapi adalah fakta bahwa mereka yang berkomitmen pada aras keagamaan hampir selalu memiliki pandangan yang jelas tentang moralitas. Hubungan antara agama dan pendidikan juga sangat erat dalam banyak kasus, dan pandangan bahwa agama harus memiliki tempat tersendiri dalam pendidikan selalu mendapat dukungan luas di negara mana pun.

\footnotetext{
${ }^{12}$ Terence W. Moore, Philosophy of Education, 48

${ }^{13}$ A. U. Akubue \& Dan Enyi (eds), Crises and Challenges in Higher Education in Developing Countries (Ibadan : Wisdom Publishers Limited, 2001), 71
} 
Hubungan antara agama dan moralitas boleh jadi tidak sepenuhnya penting bagi filsafat pendidikan tetapi menjadi penting dalam filsafat agama atau filsafat moral. ${ }^{14}$ Namun, banyak pendidik, meskipun tidak semuanya, akan menerima pandangan bahwa agama dan moral sebagai instrumen penting yang perlu dimasukkan dalam silabus pendidikan. Pandangan bahwa ajaran agama sangat diperlukan dalam pendidikan karena ia berkaitan dengan masalah moral dan bahwa tanpa agama tidak ada moralitas.

Sementara, kesulitan bisa saja muncul dari setiap upaya untuk menyamakan 'kebaikan moral' dengan 'apa yang disetujui Tuhan'. Fakta bahwa Tuhan menyetujui suatu tindakan dan fakta bahwa itu adalah tindakan yang baik secara moral adalah dua fakta yang terpisah, jika itu adalah fakta. Moralitas suatu tindakan tidak bergantung pada, juga tidak sama dengan, persetujuan Tuhan. Untuk mengetahui kehendak dan tujuan Tuhan sebagai baik secara moral, kita harus memiliki kriteria yang independen 'baik secara moral' dan kemudian menilai fakta bahwa kehendak dan tujuan Tuhan sesuai dengan itu. Tidak ada hubungan yang diperlukan antara apa yang dikehendaki Tuhan dan apa yang baik secara moral meskipun mungkin benar bahwa Tuhan hanya menghendaki apa yang baik secara moral. ${ }^{15}$

Ini semua sama dengan mengatakan bahwa agama dan moral hanya terhubung secara kontingen. Ini adalah masalah fakta bahwa secara praktis setiap agama memiliki kode moral yang dibangun di dalamnya, tetapi diragukan apakah ini lebih dari sekadar fakta. Tampaknya hal ini tidak dipandang kontradiktif dengan anggapan bahwa mungkin ada agama yang hanya memberlakukan kewajiban kehati-hatian pada penganutnya. ${ }^{16}$

Memang benar bahwa tidak semua kode moral memerlukan sanksi agama atau bergantung pada kepercayaan agama. Adalah mungkin untuk mempertahankan posisi moral yang ketat sambil menyangkal atau tidak menghakimi masalah agama. Agama mungkin, dan hampir selalu, memberikan sanksi yang kuat untuk tindakan moral ketika agen itu menganut kepercayaan agama, tetapi sanksi dan keyakinan yang menyertainya tidak diperlukan untuk moralitas, baik dalam pengertian filosofis atau praktis.

Hubungan antara agama dan pendidikan dapat ditangani dengan cara yang hampir sama dengan hubungan antara moralitas dan pendidikan. Pandangan ekstrem akan menganggap pendidikan hanya sebagai alat untuk melayani tujuan agama. Froebel cenderung menyukai pandangan seperti itu. Baginya pendidikan seorang anak adalah masalah penanaman nilai-nilai ketuhanan yang tersirat dalam diri anak tersebut. Kardinal Newman, sementara mungkin tidak mengatakannya secara eksplisit, jelas menganggap pendidikan sebagai sarana melayani tujuan keseluruhan yang sama dengan gereja tempat ia berasal.

Jadi, menginisiasi peserta didik ke dalam bidang matematika, sains dan sejarah berarti membawanya ke dalam rumah besar yang terhubung dengan tujuan Ilahi. Dalam konteks ini, pendidikan, pada dasarnya, adalah agama. Subjeknya adalah Ordo dan Penyelenggaraan Ilahi, sebagaimana diungkapkan dalam berbagai cara. Agama kemudian akan menjadi bagian dari pendidikan, atau mungkin akan lebih leluasa untuk mengatakan bahwa pendidikan adalah bagian penting dari agama. Namun demikian, ada keberatan dengan pandangan yang agak kuat tentang masalah ini. Dalam kapasitas demikian, membangun hubungan yang perlu antara agama dan pendidikan melalui serangkaian definisi atau ketentuan adalah langkah mudah tapi

\footnotetext{
${ }^{14}$ Graham Haydon, Education, Philosophy and the Ethical Environment (New York: Routledge, 2006), 95

15 Terence W. Moore, Philosophy of Education, 49

${ }^{16}$ Ibid.
} 
"kosong." Ini hanya untuk menyangkal, dengan verbalisme, kemungkinan adanya pendidikan murni sekuler..

Pandangan alternatif adalah bahwa agama dapat dianggap penting untuk diajarkan karena dimensi agama merupakan salah satu bentuk pengetahuan yang dengannya manusia dapat memahami dunia dan pengalaman mereka. Dengan demikian, agama akan mengambil tempatnya dengan sains, matematika, dan seni sebagai salah satu cara menyusun pengalaman manusia, dan karena itu diperlukan. Tanpa itu, beberapa aspek pengalaman yang signifikan tidak akan dibiarkan begitu saja. Jadi pendidikan agama akan menjadi semacam pendidikan khusus, seperti pendidikan moral, pendidikan estetika dan pendidikan matematika. Ada banyak yang bisa dikatakan untuk pandangan seperti itu. Memang benar bahwa tanpa semacam pendidikan agama, banyak dari apa yang terjadi dalam kehidupan kontemporer kita akan membingungkan jika tidak bisa dimengerti. Masyarakat kita diinformasikan dengan ideide dan tradisi keagamaan tertentu, dan sulit untuk melihat apa yang dapat dibuat seorang anak dari sekian banyaknya cara hidup manusia, melalui perkataan, kiasan, peribahasa, lembaga sosial, gereja, katedral besar, bahkan musik, lukisan, dan puisi, jika dia tidak diinisiasi ke dalam tradisi yang menjadi bagian dari pengalaman hidupnya. Tetapi, seperti yang nyatakan ketika berkaitan dengan klaim moral sebagai bagian penting dari pendidikan, inklusi agama yang 'perlu', bahkan dalam arti yang terbatas mengajar anak-anak tentang tradisi, tergantung pada pandangan pendidikan yang bersifat pasti. Jika untuk dididik melibatkan inisiasi ke semua bentuk pengetahuan, maka jika agama adalah salah satu dari bentuk-bentuk itu, 'pendidikan' memerlukan inklusinya sebagai sesuatu yang diperlukan.

\section{Pendidikan Agama dan Pengajaran}

Kalaupun pendidikan agama adalah jenis pendidikan khusus yang dapat mengambil tempat dalam kurikulum dengan jenis-jenis lain, masalah besar perlu diangkat tentang hal itu. Pendidikan agama atau studi keagamaan dapat didekati dengan dua cara yang sangat berbeda, yaitu melalui pemahaman dan komitmen. Dimasukkannya agama dalam kurikulum menjadi kebutuhan karena bertujuan memberikan informasi dan peningkatan pemahaman. Pendekatan ini menjadikan agama sebagai masalah empiris. ${ }^{17}$ Studi keagamaan akan memiliki unsurunsur sejarah dan sosial yang dibangun di dalamnya, yang bisa diperoleh dari studi antropologi atau bahkan mitologi. Dalam masyarakat multi-budaya ada kasus yang menarik di mana beberapa bentuk studi agama perbandingan dimasukkan dalam kurikulum, baik karena alasan intelektual atau sosial. Sementara pendekatan pendidikan agama melalui komitmen lebih sulit karena selain mengajarkan kepada anakpeserta didik tentang agama, juga berusaha membuat mereka memiliki komitmen untuk memegang teguh prinsip-prinsip agama agar dipraktekkan dalam kehidupan sehari-hari mereka. Sejauh apa yang diajarkan adalah tentang agama, tentang asal-usul dan perkembangannya, bentuknya, ritualnya, kepercayaan dan praktiknya, mereka juga bertanggung jawab atas pelaksanaannya. Apa yang diajarkan kepada peserta didik, dengan demikian, akan mempengaruhi perilakunya dalam kehidupan seharihari.

Adalah mungkin dan memang bermanfaat untuk mengambil posisi perantara antara pandangan pendidikan agama yang melihatnya hanya sebagai transfer pengetahuan tentang

\footnotetext{
${ }^{17}$ Lihat Ralph W. Hood, Jr., Peter C. Hill, Bernard Spilka, The Psychology of Religion: An Empirical Approach (New York, London: The Guilford Press, 2018)
} 
agama dan pandangan yang mengharuskannya untuk memberikan rasa komitmen. Guru dapat mencoba mengembangkan kesadaran religius pada peserta didik, dengan membuat mereka memahami bagaimana kehidupan terlihat, katakanlah, kehidupan para nabi. Ini akan membantu memberikan perspektif tentang dunia yang akan diperlukan sebelum mereka bisa benar-benar berada dalam posisi memilih dan berkomitmen sendiri pada agama tertentu yang dianutnya.

Dalam membuat perbedaan antara pengetahuan tentang fakta empiris dan komitmen terhadap doktrin kita dihadapkan dengan masalah yang muncul juga dalam penilaian pendidikan moral. Apa yang bisa dikatakan tentang seseorang yang memiliki pengetahuan terperinci tentang agama sebagai realitas manusia, sejarah, dan kelembagaan, tidak serta merta memilki komitmen pada doktrin atau kepercayaan agama. Dalam hal ini, kita mungkin harus mengatakan bahwa dia tahu banyak tentang agama tetapi bukan orang yang religius. Seperti juga kalau dikatakan bahwa seseorang memiliki banyak pemahaman moral tetapi tidak serta merta dia dianggap sebagai pribadi yang bermoral.

\section{Penutup}

Berangkat dari pembahasan tentang hubungan antara moral dan agama, dan apa kontribusi kedua bidang ini dalam pendidikan, dapat disimpulkan bahwa makna pendidikan, moral dan agama, juga dengan pembenaran atas moralitas dan agama merupakan instrumen penting untuk dimasukkan ke dalam kurikulum.

Pendidikan moral dan pendidikan agama adalah bentuk-bentuk pendidikan yang spesifik, yang diperlukan untuk mewujudkan pendidikan yang lengkap, tetapi keduanya tidak berarti akan menjadi keseluruhan tujuan pendidikan. Pendidikan moral, demikian dikatakan, mengajarkan peserta didik pengetahuan tentang apa yang harus dilakukan terkait dengan perilaku yang memengaruhi kesejahteraan atau kebahagiaan mereka dan orang lain, termasuk pemahaman tentang alasan di balik perilaku moral tersebut. Karena pendidikan moral terkait erat dengan pelatihan moral, seseorang yang berpendidikan, secara moral, akan menjadi orang yang tidak hanya tahu apa yang harus ia lakukan dan mengapa ia harus melakukannya, tetapi juga cenderung bertindak secara konsisten dalam terang pengetahuan ini. Pendidikan agama, juga, mengajarkan kepada peserta didik pengetahuan tentang agama, juga upayanya agar mereka memiliki komitmen pada keyakinan akan kebenaran doktrin agama yang mereka anut.

\section{Daftar Rujukan}

Aikara, Jacob. Education: Sociological Perspective. New Delhi: Rawat Publications, 2004

Akubue A. U. \& Enyi, Dan (eds). Crises and Challenges in Higher Education in Developing Countries. Ibadan : Wisdom Publishers Limited, 2001

Bull, Norman J. Moral Education. New York: Rotledge, 2010

Billington, Ray. Living Philosophy: An Introduction to Moral Thought. London and New York: Routledge, 2003

Bloomfield, Paul. Morality and Self-Interest. Oxford: Oxford University Press, 2008

Haydon,Graham. Education, Philosophy and the Ethical Environment. New York: Routledge, 2006 
Hood, Jr., Ralph W. Hill, Peter C. Spilka, Bernard. The Psychology of Religion: An Empirical Approach. New York, London: The Guilford Press, 2018

Moore, Terence W. Philosophy of Education. London: Routledge, 2010

Pozgar, George D. Legal and Ethical Issues for Health Professionals. Burlington: Jones\&Bartlett Learning, 2019

Shanahan, Mary (ed). Does Religious Education Matter?. London: Routledge, 2016

Shah, Saeeda. Education, Leadership and Islam: Theories, Discource and Practices from Islamic Perspective. New York: Routledge, 2016

Troost, Cornelius J. Radical School Reform; Critique and Alternatives, Boston: Little, Brown, 1973 